\title{
Biomass and Protein Yields of Field Peas and Oats Intercrop Affected by Sowing Norms and Nitrogen Fertilizer at Two Different Stages of Growth
}

\author{
Ivan Krga ${ }^{1, *}$, Aleksandar Simić ${ }^{2}\left(\right.$, Željko Dželetović ${ }^{3}{ }^{10}$, Snežana Babić ${ }^{4}$, Snežana Katanski ${ }^{5}$, \\ Svetlana Roljević Nikolić ${ }^{6}(\mathbb{D})$ and Jelena Damnjanović ${ }^{1}$ \\ 1 Institute for Vegetable Crops, Karađorđeva 71, 11420 Smederevska Palanka, Serbia; \\ jelena.damnjanovic@gmail.com \\ 2 Faculty of Agriculture, Department for Field and Vegetable Crops, University of Belgrade, Nemanjina 6, \\ 11080 Belgrade, Serbia; simical@gmail.com \\ 3 Institute for Applied Nuclear Energy, Banatska 31b, 11080 Belgrade, Serbia; zdzeletovic@inep.co.rs \\ 4 Institute for Forage Crops, Globoder, 37251 Kruševac, Serbia; snezana.babic@ikbks.com \\ 5 Institute of Field and Vegetable Crops, Maksima Gorkog 30, 21000 Novi Sad, Serbia; \\ snezana.katanski@ifvens.ns.ac.rs \\ 6 Institute of Agricultural Economics, Volgina 15, 11060 Belgrade, Serbia; svetlana_r@iep.bg.ac.rs \\ * Correspondence: ivan.krga@yahoo.com
}

Citation: Krga, I.; Simić, A.; Dželetović, Ž.; Babić, S.; Katanski, S.; Nikolić, S.R.; Damnjanović, J.

Biomass and Protein Yields of Field Peas and Oats Intercrop Affected by Sowing Norms and Nitrogen Fertilizer at Two Different Stages of Growth. Agriculture 2021, 11, 871. https://doi.org/10.3390/ agriculture11090871

Received: 27 July 2021

Accepted: 3 September 2021

Published: 10 September 2021

Publisher's Note: MDPI stays neutral with regard to jurisdictional claims in published maps and institutional affiliations.

Copyright: () 2021 by the authors. Licensee MDPI, Basel, Switzerland. This article is an open access article distributed under the terms and conditions of the Creative Commons Attribution (CC BY) license (https:// creativecommons.org/licenses/by/ $4.0 /)$.

\begin{abstract}
In limited growing conditions, intercropped field peas and oats can represent a significant source of forage rich in protein. If applied correctly, factors such as nitrogen fertilizer, the mowing phase, and sowing norms can significantly increase the productivity of these mixtures. Field trials were conducted to examine their productivity under different nitrogen levels $\left(0,40,80 \mathrm{~kg} \mathrm{ha}^{-1}\right)$, different sowing norms /mixtures (field peas: oats-100:15\%; 100:30\%), and two stages of growth (full flowering, full pod formation). Nitrogen fertilizer and different sowing norms had a significant effect on the biomass, hay, and crude protein yields. On average, the highest hay yields were achieved with $80 \mathrm{~kg} \mathrm{ha}^{-1} \mathrm{~N}\left(4.96 \mathrm{tha}^{-1}\right)$, followed by $40 \mathrm{~kg} \mathrm{ha}^{-1} \mathrm{~N}\left(4.27 \mathrm{tha}^{-1}\right)$. The highest protein yields were achieved with $40 \mathrm{~kg} \mathrm{ha}^{-1} \mathrm{~N}\left(\mathrm{CP}-704.1 \mathrm{~kg} \mathrm{ha}^{-1}\right)$, followed by $80 \mathrm{~kg} \mathrm{ha}^{-1} \mathrm{~N}\left(\mathrm{CP}-637.6 \mathrm{~kg} \mathrm{ha}^{-1}\right)$. Sowing norm 100:30\% achieved higher hay yields: 100:30\%-4.82 $\mathrm{tha}^{-1} ; 100: 15 \%-4.44 \mathrm{t} \mathrm{ha}^{-1}$, while 100:15\% achieved higher crude protein yields: $100: 15 \%-730.4 \mathrm{~kg} \mathrm{ha}^{-1} ; 100: 30 \%-692.7 \mathrm{~kg} \mathrm{ha}^{-1}$ on average. The costs were not significantly increased with the nitrogen fertilizer, but the net profits were increased by as much as $163 \%$, depending on the nitrogen level and the mixture. Nitrogen fertilizer also achieves higher economic efficiency for the mixture 100:15\% compared to the 100:30\% mixture. Mixtures of field peas and oats outperform single-grown crops and provide cost-effective feed for a short time. Using optimal seed ratios and nitrogen fertilizer can significantly increase the productivity and profitability of the feed with minimal impact on the overall production costs.
\end{abstract}

Keywords: additive series; cereals; forage; intercropping; legumes; mixture; nitrogen fertilizer; phenophase

\section{Introduction}

The current situation in the agriculture of Serbia and other European countries shows a decline in quality forage, as some research suggests that many of these countries are dependent on the import of protein feeds [1]. In Serbia, forage feeds are obtained from meadows and pastures (perennial grasses and legumes), field crops (annual legumes and cereals, Brassicaceae), and, to some extent, crop and processing residues. However, most of the forage feeds come from just a few species or groups, such as maize silage, alfalfa hay, and hay from meadows and pastures. These feeds are primarily dominated by carbohydrates and fibers, except in alfalfa crops. Furthermore, soils that are used in agricultural production are often excessively used and not adequately maintained. This approach has a long-lasting negative effect on the environment, the quality of the soil, and 
the feed produced. In some agricultural regions in Serbia, improper agricultural practice and other anthropogenic factors have led to increased soil degradation and a lack of organic matter in the soil [2]. Decreases in soil quality and biodiversity have been observed across many European countries [3]. This situation requires urgent changes and adaptations to the changing environment and climate since intensive agriculture is a significant contributing factor. One way to handle the negative impacts of modern plant production is the practice of intercropping. Intercropping legumes and grasses or cereals for forage provides a viable and fast solution for on-farm protein production since it increases biodiversity and provides other benefits for animals, soil, and the environment.

The most significant advantages of intercropping legumes and cereals or grasses are the increased yields compared to sole stands [4-7], and better and more balanced biomass quality regarding proteins and energy [8]. Intercropped species better utilize nitrogen and other nutrients from the soil $[9,10]$, as well as soil moisture and solar radiation, while other research highlights the benefits on the soil microorganisms [11]. The research thus far mentions several other benefits and, in particular, nitrogen transfer from the roots of legumes to the roots of different cereals or grasses [12-14]. Nitrogen transfer combined with the nitrogen fixation by the bacteria located on the roots of the legumes can significantly reduce the need for nitrogen fertilizers while also enriching the soil with this element. Combining legumes with grasses or cereals can provide some processing advantages, such as canning, since producing silage from legume species alone is challenging.

Regarding the cultivation of annual legumes and cereals for forage, field peas (Pisum sativum ssp. arvense L.) and oats (Avena sativa L.) mixtures provide decent yields and quality feed with very basic cultivation needs. They are characterized by a short production period (average 2 months) and are reasonably suitable for limited growing conditions. Some research suggests that the best performance of mixtures compared to pure stands is achieved where the soil nitrogen is scarce [15]. In the temperate climate, species whose vegetation period ends before extreme summer temperatures and droughts are more reliable for cultivation, and this includes field peas and oats cultivated for biomass. Field peas mixed with oats or other species also have great potential in weed control compared to sole crops [7,16-18]. Field pea and oat can also achieve higher dry matter yields and productivity (LER) when compared to intercrops of field pea with other cereals $[4,19,20]$.

In most cases, intercropped legumes with cereals give better results and have many benefits on the overall production. However, some factors can significantly affect their yield and quality. One such factor is the application of nitrogen fertilizer, which is very specific to field pea and its mixtures due to the possibility of nitrogen fixation in peas. Other factors with significant impact on the yield and quality are the crop development stage and the ratio of two species in the sowing norm. Accordingly, changes in the sowing norm can directly affect changes in chemical composition as well as yield. It is crucial to understand these factors and their impact since oats, like some other cereals, are considered more competitive for the resources compared to field peas [21-23]. Cereals also react more strongly to nitrogen fertilizer $[21,24]$ because they do not have the natural ability for its fixation, while legumes provide most of the nitrogen, $30-80 \%$, on their own. Furthermore, increased nitrogen use can reduce plant productivity by inhibiting nitrogenfixating bacteria [25]. Using fertilizers above the optimal threshold can increase the cereal components in the mixture and alter the chemical composition of the feed, as well as increase the overall inputs. In that regard, is important to understand the economic aspects of nitrogen fertilizer use and the general productivity of these mixtures. Research on this topic seems to be limited, thus, one goal of this research is to examine the profitability of field peas and oat mixtures on-farm. From the production standpoint, the focus of this research was to examine how different sowing norms and nitrogen fertilizer rates affect the biomass and protein yields of field peas and oats when they are intercropped using additive method series. Some basic relations were examined between the two species, and the crops were harvested at two stages of growth to find the most optimal moment for their harvest. 


\section{Materials and Methods}

Field trials were set up on the experimental fields of the Institute of Animal Husbandry in Zemun Polje, Belgrade, Serbia ( $44^{\circ} 50^{\prime} 18.9^{\prime \prime} \mathrm{NW}$ and $20^{\circ} 17^{\prime} 0.6^{\prime \prime} \mathrm{E}, 66 \mathrm{~m}$ a.s.l.). The experiment was performed over three consecutive years $(2016,2017,2018)$ as a spring crop in dry farming (no irrigation). The order of each operation is presented in Table 1.

Table 1. Most important cultivation operations.

\begin{tabular}{ccc}
\hline $\begin{array}{c}\text { 1. Deep plowing was carried out in the } \\
\text { fall to a depth of } 25 \mathrm{~cm} .\end{array}$ & $\begin{array}{c}\text { 2. Phosphorus and potassium fertilizer } \\
\text { was applied approximately one month } \\
\text { before sowing. }\end{array}$ & $\begin{array}{c}\text { 3. Seedbed preparation was carried out } \\
\text { several days before sowing (5 } \mathrm{cm} \text { depth). }\end{array}$ \\
\hline $\begin{array}{c}\text { 4. Sowing was performed manually in } \\
\text { strips, row spacing } 15 \mathrm{~cm} \text {, in the second } \\
\text { half of March. }\end{array}$ & $\begin{array}{c}\text { 5. Seed rates were } 150 \mathrm{~kg} \mathrm{ha}^{-1} \text { for full } \\
\text { sowing norms }(100 \%) \text { for both species. }\end{array}$ & $\begin{array}{c}\text { 6. Nitrogen was applied when the first } \\
\text { true leaves were formed. }\end{array}$ \\
\hline $\begin{array}{c}\text { 7. After sowing, the experimental plot } \\
\text { was rolled to ensure better contact } \\
\text { between the seeds and the soil. }\end{array}$ & $\begin{array}{c}\text { 8. Weed removal was performed } \\
\text { manually and when necessary. }\end{array}$ & $\begin{array}{c}\text { 9. Harvest was carried out } 70-75 \text { days } \\
\text { after the sowing (full flowering and full } \\
\text { pod formation stage). }\end{array}$ \\
\hline
\end{tabular}

\subsection{Trial Design}

The three-factorial experiment was set according to the randomized block design with four repetitions. The size of the subplot was $12 \mathrm{~m}^{2}$. The first half of the subplot $\left(6 \mathrm{~m}^{2}\right)$ was used for sampling in the first stage of harvest (full flowering stage). The second half of the subplot was used for the second stage of harvest (full pod formation). Cultivars used in this experiment were cultivar Junior (field peas) and cultivar Dunav (oats). Production capacity and the effect of each factor were measured by examining the biomass and hay yields, the share of two species in the yield, land equivalent ratio (LER), plant height, and the number of internodes of field peas as well as protein yields. Tested factors and their particular levels are presented in Table 2.

Table 2. Tested factors and their levels.

\begin{tabular}{|c|c|c|c|c|c|c|}
\hline \multirow{2}{*}{$\begin{array}{c}\text { Harvest Period } \\
\text { Nitrogen }\end{array}$} & \multicolumn{3}{|c|}{$\begin{array}{l}\text { I-Approx. 65-70 Days after the Sowing } \\
\text { (Full Flowering Phase, BBCH 65-70) }\end{array}$} & \multicolumn{3}{|c|}{$\begin{array}{l}\text { II-Approx. } 75 \text { Days after the Sowing } \\
\text { (Full Pod Formation Phase, BBCH 75-76) }\end{array}$} \\
\hline & $0 \mathrm{~kg} \mathrm{ha}^{-1} \mathrm{~N}$ & $40 \mathrm{~kg} \mathrm{ha}^{-1} \mathrm{~N}$ & $80 \mathrm{~kg} \mathrm{ha}^{-1} \mathrm{~N}$ & $0 \mathrm{~kg} \mathrm{ha}^{-1} \mathrm{~N}$ & $40 \mathrm{~kg} \mathrm{ha}^{-1} \mathrm{~N}$ & $80 \mathrm{~kg} \mathrm{ha}^{-1} \mathrm{~N}$ \\
\hline \multirow{4}{*}{ Crops/Mixtures } & Oats & Oats & Oats & Oats & Oats & Oats \\
\hline & F. pea & F. pea & F. pea & F. pea & F. pea & F. pea \\
\hline & $100: 15 \%$ & $100: 15 \%$ & $100: 15 \%$ & $100: 15 \%$ & $100: 15 \%$ & $100: 15 \%$ \\
\hline & $100: 30 \%$ & $100: 30 \%$ & $100: 30 \%$ & $100: 30 \%$ & $100: 30 \%$ & $100: 30 \%$ \\
\hline
\end{tabular}

$\mathrm{BBCH}-\mathrm{BBCH}$ scale is a system for a uniform coding of phenologically similar growth stages of all mono- and dicotyledonous plant species. Ref. [26], where numbers represent the days after sowing and correspond to the particular stage of plant development; F. pea-field peas.

The additive method was used for intercropping, and the sowing ratio of the mixture was peas: oats-100\%: $15 \%$ and 100\%: $30 \%$ (150:15 $\mathrm{kg} \mathrm{ha}^{-1}$ of seed; $150: 30 \mathrm{~kg} \mathrm{ha}^{-1}$ of seed, respectively). These levels were selected according to previous experiences and research that indicates the high competitiveness of oats and other cereals over field peas $[6,21-23]$. In addition to the mixture, field peas and oats were grown individually as a control $(100 \%$ of their full sowing norm-150 $\mathrm{kg} \mathrm{ha}^{-1}$ ).

Mowing was performed during two phenophases, the phenophase of full flowering and the phenophase of full pod formation. The stages of development were determined by evaluating the plants on $1 \mathrm{~m}^{2}$ randomly selected in the subplots. The first phase of mowing was conducted when at least $50 \%$ of the flowers were fully open $(\mathrm{BBCH} 65-70)$. The second phase of mowing was conducted when at least $50 \%$ of pods had reached their full length (BBCH 75-76) [26]. 
Two levels of nitrogen were tested, 40 and $80 \mathrm{~kg} \mathrm{ha}^{-1}$, with control, $0 \mathrm{~kg} \mathrm{ha}^{-1} \mathrm{~N}$. The nitrogen was applied by hand to each subplot and with the dedicated quantities according to the design.

\subsection{Plant and Yield Measurements}

The biomass yields were established by measuring the mowed biomass from half of the subplot $\left(6 \mathrm{~m}^{2}\right)$ using a digital scale. The dry mass used to calculate the hay yield was obtained by drying $1 \mathrm{~kg}$ of fresh biomass in an oven at a temperature of $65^{\circ} \mathrm{C}$. Dried mass was measured on a digital scale. The share of field peas in the yield was measured from biomass sampled on $1 \mathrm{~m}^{2}$ of a randomly selected area in each subplot. Plant height and the number of internodes were measured by taking 10 plants for each species from each subplot. Overall, 40 plants were measured for each treatment. Mowing of plants was performed with a hand mower at a height of $5-7 \mathrm{~cm}$. Protein content was obtained on a TECATOR Kjeltec AutoAnalyzer 1030 (Protein (Crude)) in animal feed and pet food by the Kjeldahl method [27]. The obtained content was translated into protein yield per hectare.

\subsection{Soil and Meteorological Conditions}

Phosphorus and potassium fertilizers were used as a starting fertilizer to correct the content of these elements in the soil. Based on the chemical analysis of the soil performed for a layer of $0-20 \mathrm{~cm}$ (Table 3 ) and the needs of cultivated crops, the amounts of phosphorus and potassium were calculated and evenly applied over the entire experimental field. In the first and second years, $80 \mathrm{~kg} \mathrm{ha}^{-1} \mathrm{P}_{2} \mathrm{O}_{5}$ and $50 \mathrm{~kg} \mathrm{ha}^{-1} \mathrm{~K}_{2} \mathrm{O}$ were applied. In the third year, phosphorus application was omitted since there were sufficient quantities in the soil, and only $50 \mathrm{~kg} \mathrm{ha}^{-1} \mathrm{~K}_{2} \mathrm{O}$ was applied.

Table 3. Soil characteristics in three years, Zemun Polje, Belgrade.

\begin{tabular}{|c|c|c|c|c|c|c|}
\hline Year & Organic Matter \% & pH Value (KCl) & pH Value $\left(\mathrm{H}_{2} \mathrm{O}\right)$ & $\mathbf{N} \%$ & $\mathrm{P}_{2} \mathrm{O}_{5} \mathrm{mg} 100 \mathrm{~g}^{-1}$ & $\mathrm{~K}_{2} \mathrm{O} \mathrm{mg} 100 \mathrm{~g}^{-1}$ \\
\hline 2016 & 2.163 & 6.32 & 7.05 & 0.06 & 0.2 & 12.3 \\
\hline 2017 & 3.14 & 4.9 & 5.91 & 0.14 & 4.97 & 19.84 \\
\hline 2018 & 2.77 & 6.43 & 7.36 & 0.2 & 42.65 & 21.56 \\
\hline
\end{tabular}

During the experiment, meteorological factors were monitored and recorded for the months of importance for these crops. The values of the GRF were calculated from the obtained results (Figure 1). Climate trends portrayed by GRF show climate changes throughout the growing period of crops.

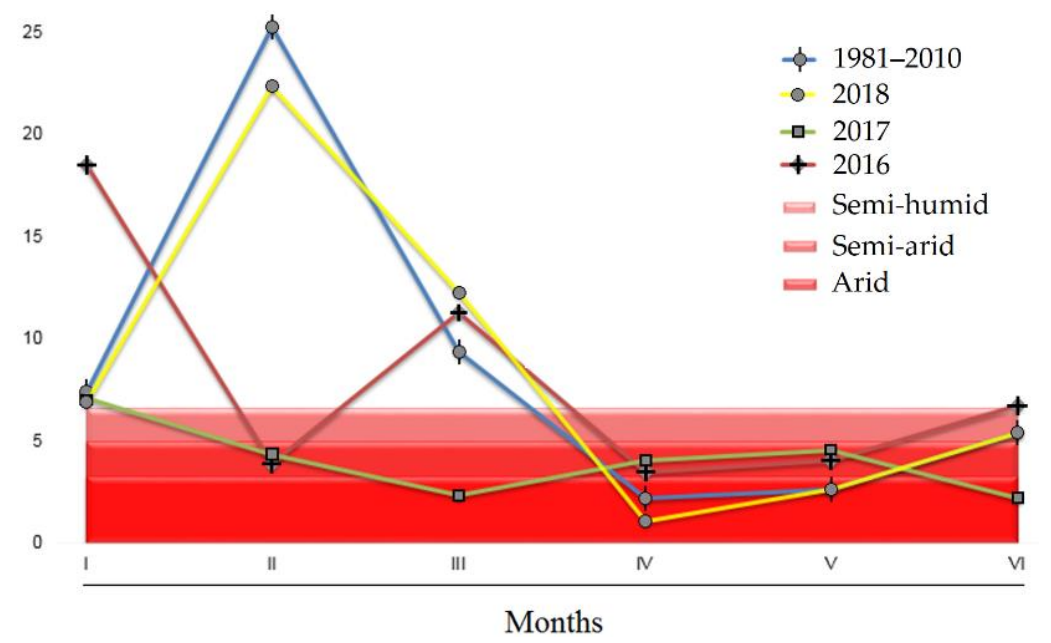

Figure 1. Gračanin's rain factor (GRF) for growing seasons $(2016,2017,2018)$ and referent period (1981-2010). 


\subsection{Statistical Analysis}

Gračanin rain factor (GRF) [28] represents a relationship between the sum of monthly precipitations and the mean monthly temperatures for each month. The formula is calculated with GRF = SMP / AMT; SMP — the sum of monthly precipitations; AMT—average monthly temperatures. According to this indicator, months are classified as arid up to 3.3; semiarid 3.3-5.0; semi-humid 5.0-6.6; humid 6.6-13.3; and perhumid above 13.3.

LER (land equivalent ratio) is a standardized index defined as the area required by sole crops to produce the same yield as mixed crops [29]. It is calculated using the following formula:

$\mathrm{LER}=\mathrm{YPM} / \mathrm{YPS}+\mathrm{YOM} / \mathrm{YOS}$, where YPM is the yield of field peas in the mixture, YPS - yield of field peas as a single grown crop; YOM-yield of oats in the mixture, YOSyield of oats as a single grown crop.

Index LER can be greater than 1, less than, or equal to 1 . Higher values than one indicate the superiority of intercrops compared to sole crops, while lower values indicate the inferiority of the intercrops.

Recorded values for plant height, number of internodes, the share of field peas in the yield, LER, biomass and hay yield, and protein yield were processed with analysis of variance (ANOVA) for the three-factorial experiment with randomized block design. The test of significance was calculated using the F test $(p<0.05$ and $p<0.01)$.

\subsection{Economic Efficiency}

The economic efficiency of different treatments was calculated to determine the profitability of mixtures of field peas and oats produced on-farm. Economic inputs included all expenses: seed, fertilizer, machinery services, and labor force. The economic output included the hay yields of field pea and oat mixture evaluated at the current market value. The official price list of mechanical services for 2021 was used to determine the costs of mechanization. This list is issued by the Cooperative Association of Vojvodina and is valid for the whole Serbia, while the prices of raw materials were obtained by market research. Analytical calculation based on variable costs was performed using the following formula [30]:

$$
\mathrm{CM}=\mathrm{PV}-\mathrm{VC} \text {, while PV }=(\mathrm{v} \times \mathrm{p})+\mathrm{s}
$$

where analytical elements represent:

$\mathrm{CM}-$ contribution margin (coverage of variable costs);

$\mathrm{PV}$-achieved production value;

VC—gained variable costs;

$\mathrm{v}$ - the volume of product per unit of measure;

$\mathrm{p}$-the price of the product per unit measure;

s-subsidies per unit of production area.

Economic efficiency is calculated as [31]:

$$
\begin{gathered}
\text { Net returns }=\text { Total output }- \text { Total input } \\
\text { Benefit Cost ratio = Net returns } / \text { Total input }
\end{gathered}
$$

\section{Results}

The chemical analysis of the soil showed that its quality had high variations on a year-to-year basis. In particular, the nitrogen content was below average in the first and the second year, while it was average in the third experimental year. The analysis further showed low phosphorus content in the first year, high in the second, and very high in the third experimental year. The potassium content was below average in the first experimental year and above average in the second and third experimental years. The values were compared to the standards for top-soils across Europe [32].

The pre-vegetation period in the first and the third experimental year was relatively favorable, while the second year (2017) was arid to semi-arid (Figure 1). The most signifi- 
cant period for the formation of the aboveground mass (April, May) was arid to semi-arid for all three experimental years. This trend coincided with the reference values, and it shows that the period April-May is usually an arid period for this region.

\subsection{Field Pea and Oat Yields and Yield Components}

In all three years, the plants of field pea were significantly $(p<0.01)$ taller in the second mowing phase compared to the first mowing phase (Table 4). These differences were recorded equally for single-grown field pea and its mixtures with oats in all three years of research. For the second and the third year, plants were significantly higher in the single-grown field pea compared to its mixtures. Interactions were recorded in the second year between crop and nitrogen $(p<0.01)$, and phase, crop and nitrogen $(p<0.05)$.

The higher number of internodes was measured in the second mowing phase compared to the first for all three years; however, these differences were not significant in the third year. The significantly higher number of internodes in the second mowing phase, for both mixtures and sole crops, was measured in the first year only. In the first and the third year $(2016,2018)$, the higher number of internodes of field pea was measured in the mixture compared to sole field pea. There were no significant interactions for this trait.

In three years of testing, a significant influence of all three factors on the biomass yield was measured for the field pea and oats intercrops $(p<0.01)$. Interaction between the mowing phase, sowing norm, and nitrogen was found for all three years of testing $(p<0.05$, $p<0.01, p<0.05$, respectively). Analysis has also shown first-order interactions between different sowing norms and nitrogen in the second $(p<0.01)$ and the third year $(p<0.05)$, as well as phase and nitrogen interaction in the second year $(p<0.01)$ (Table 4$)$. Significantly higher yields of biomass were achieved in the first mowing phase compared to the second mowing phase. In all three years, this is equally measured for both species and their mixtures. Overall the lowest biomass yields were measured in single-grown field pea. The highest biomass yields were measured in the 100:30\% mixture for all three years and oats in the first and second experimental years. Mixture 100:15\% achieved the highest yields along with the 100:30\% mixture and sole oats only in the first year (average $19.94 \mathrm{tha}^{-1}$ ). Nitrogen fertilizer had a significant effect on all crops. On average, the highest yields were achieved with $80 \mathrm{~kg} \mathrm{ha}^{-1} \mathrm{~N}\left(21.28 \mathrm{tha}^{-1}\right)$, followed by $40 \mathrm{~kg} \mathrm{ha}^{-1} \mathrm{~N}\left(19.35 \mathrm{t} \mathrm{ha}^{-1}\right)$, and the lowest without nitrogen fertilizer $\left(17.75 \mathrm{tha}^{-1}\right)$. This trend of biomass yield increase from 0 to $80 \mathrm{~kg} \mathrm{~N} \mathrm{ha}^{-1}$ has been observed for all three years and all mixtures and sole crops independently, with only one exception of field pea in the third year. On average, nitrogen had the highest impact on the yield of oats, where the difference between control and the fertilized crop is $5.15 \mathrm{t} \mathrm{ha}^{-1}$ of raw mass. For field peas, these differences are $2.02 \mathrm{t} \mathrm{ha}^{-1}$, for mixtures $100: 15 \%-3.29 \mathrm{tha}^{-1}$ and mixture $100: 30 \%-3.67 \mathrm{t} \mathrm{ha}^{-1}$.

Following a similar trend to biomass yields, hay yields were significantly affected by all factors, except for the mowing phase in the first year. No significant interactions have been observed in the first year. In the second year, first-order interactions have been recorded between all tested factors (phase $\times$ crop, phase $\times$ nitrogen, crop $\times$ nitrogen) with high significance $(p<0.01)$, as well as second-order interaction between all tested factors $(p<0.05)$. In the third experimental year, first-order interactions have been recorded between the mowing phase and nitrogen $(p<0.05)$, crop and nitrogen $(p<0.05)$, as well as second-order interactions between all tested factors $(p<0.01)$. Mixtures and sole crops had varying yields depending on the time of their harvest and the year. Regarding the crop factor, the highest yields have been recorded for sole oats in the first and the third year (average $4.99 \mathrm{t} \mathrm{ha}^{-1}$ ) and mixture 100:30\% in the second and the third year (average $4.82 \mathrm{tha}^{-1}$ ), followed by a mixture $100: 15 \%$ (average $4.44 \mathrm{tha}^{-1}$ ), and sole field pea (average $3.17 \mathrm{t} \mathrm{ha}^{-1}$ ). Nitrogen fertilizer increases the yields of hay for mixtures as well as sole crops (Figure 2). However, some differences within the particular treatments are notably present in the third year (Figure 3). It is important to note that the third year had the highest amount of natural nitrogen in the soil and the best soil quality overall. Consequently, the nitrogen fertilizer in the third year most certainly had a diminishing 
effect as compared to the second year, which had lower soil quality and nitrogen content. On average, the highest yields were achieved with $80 \mathrm{~kg} \mathrm{ha}^{-1} \mathrm{~N}\left(4.99 \mathrm{t} \mathrm{ha}^{-1}\right)$, lower with $40 \mathrm{~kg} \mathrm{ha}^{-1} \mathrm{~N}\left(4.27 \mathrm{t} \mathrm{ha}^{-1}\right)$, and the lowest with the control treatment, $0 \mathrm{~kg} \mathrm{ha}^{-1} \mathrm{~N}$ $\left(3.82 \mathrm{tha}^{-1}\right)$.

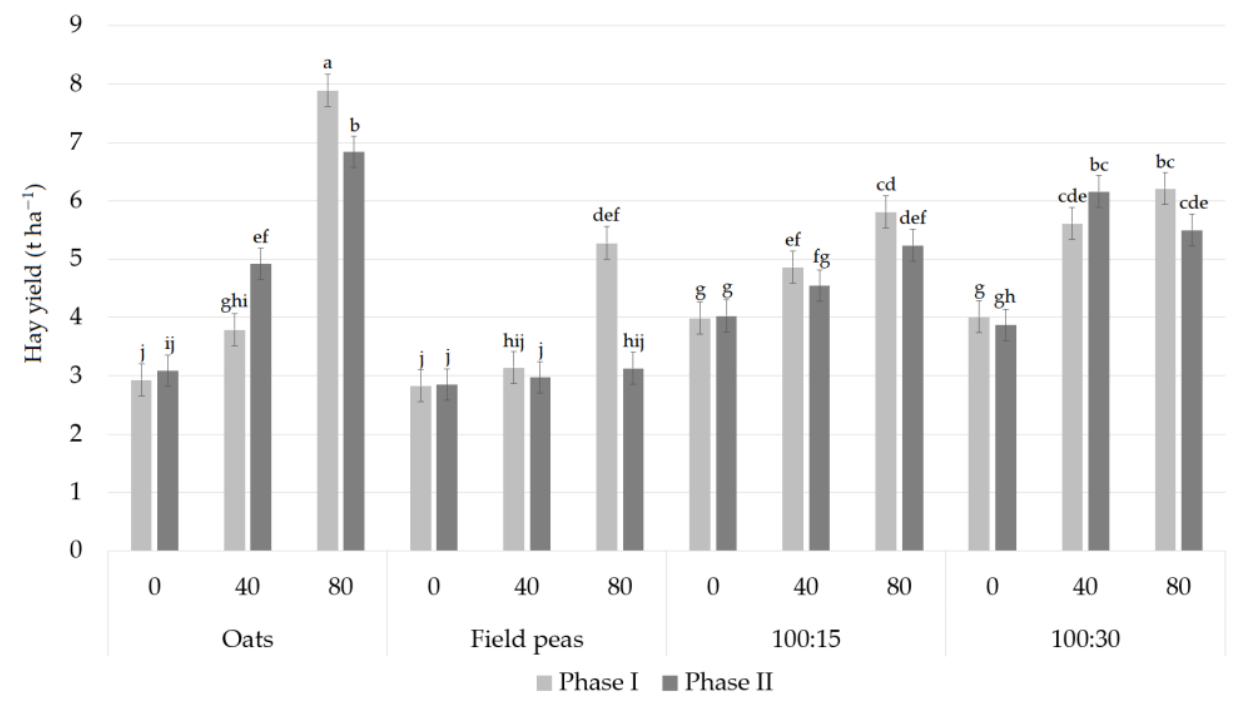

Figure 2. Hay yield of sole crops and their mixture under nitrogen fertilizer $\left(0 \mathrm{~kg} \mathrm{ha}^{-1}, 40 \mathrm{~kg} \mathrm{ha}^{-1}\right.$, $80 \mathrm{~kg} \mathrm{ha}^{-1}$ ) and two mowing phases (2017); error bars—standard error; ${ }^{a-j}$ —significant differences between different treatments, ${ }^{\text {a }}$ representing the highest value, etc.

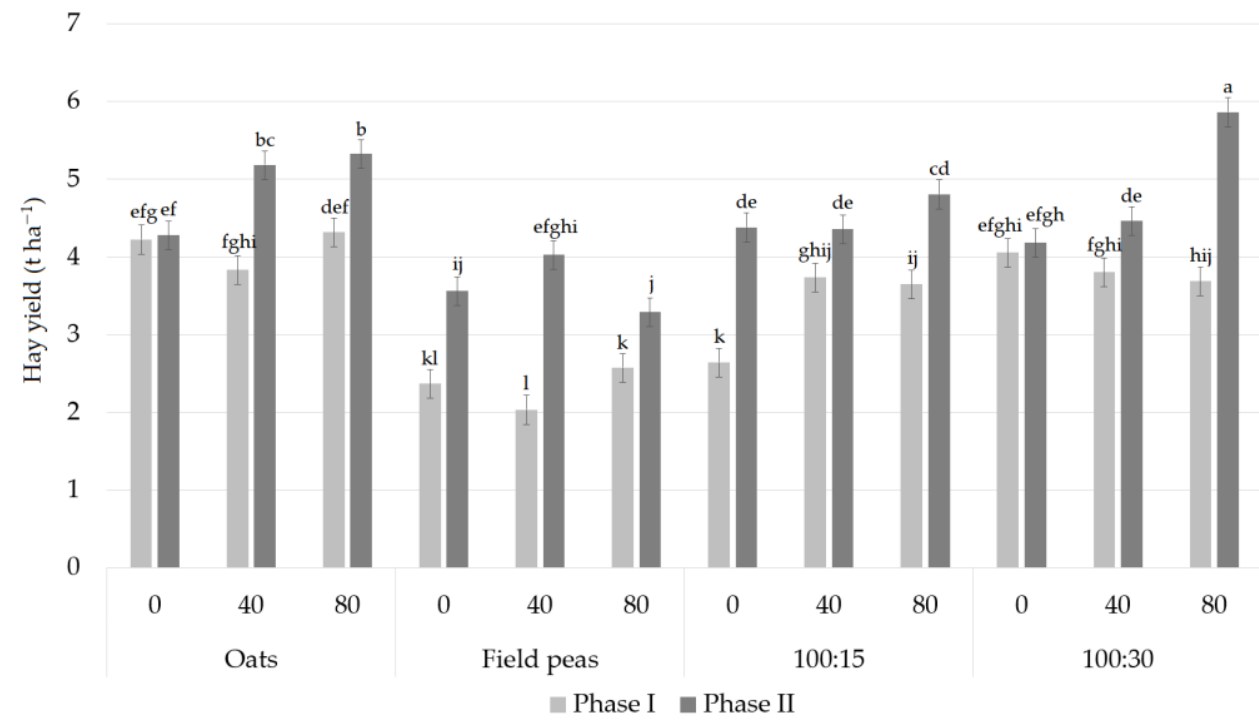

Figure 3. Hay yield of sole crops and their mixture under nitrogen fertilizer $\left(0 \mathrm{~kg} \mathrm{ha}^{-1}, 40 \mathrm{~kg} \mathrm{ha}^{-1}\right.$, $80 \mathrm{~kg} \mathrm{ha}^{-1}$ ) and two mowing phases (2018); error bars—standard error; ${ }^{\mathrm{a}-1}$ - significant differences between different treatments, ${ }^{\mathrm{a}}$ representing the highest value, etc.

A significant effect of all tested factors was observed for crude protein yields. Firstorder interactions were recorded between phase and mixture $(p<0.01)$. First and secondorder interactions were recorded for all tested factors in the second and the third year $(p<0.01)$. In the first and the second experimental year, crude protein yields were higher in the first phase compared to the second, while in the third year, yields were higher in the second mowing phase. Values for three years of testing show the highest protein yields for a sowing norm of 100:15\% (average $730.4 \mathrm{~kg} \mathrm{ha}^{-1}$ ), followed by the 100:30\% mixture $\left(692.7 \mathrm{~kg} \mathrm{ha}^{-1}\right)$, field peas $\left(633.5 \mathrm{~kg} \mathrm{ha}^{-1}\right)$, while the lowest yields of crude proteins were 
obtained from pure oats $\left(456.1 \mathrm{~kg} \mathrm{ha}^{-1}\right)$. On average, the mixture 100:15\% achieved higher protein yields compared to $100: 30 \%$ in all three years. These differences were not as significant in the second and the third year when we observed only averages. However, when the nitrogen is excluded, mixture 100:15\% achieves significantly higher protein yields compared to the 100:30\% mixture in all three years (Figures 4-6). Only once the nitrogen is applied do the protein yields of the 100:30\% mixture achieve similar yields to the $100: 15 \%$ mixture. Regardless, across mixtures and sole crops, the best results are achieved with the addition of nitrogen compared to the control treatments, $80 \mathrm{~kg} \mathrm{ha}^{-1}$ $\mathrm{N}$-average $704.1 \mathrm{~kg} \mathrm{ha}^{-1}$, followed by $40 \mathrm{~kg} \mathrm{ha}^{-1} \mathrm{~N}$-average $637.6 \mathrm{~kg} \mathrm{ha}^{-1} \mathrm{~N}$, and $0 \mathrm{~kg} \mathrm{ha}^{-1} \mathrm{~N}$-average $542.9 \mathrm{~kg} \mathrm{ha}^{-1}$. In terms of the mowing phase, the yields were highly dependent on the particular mixture or sole crop and the year of testing.

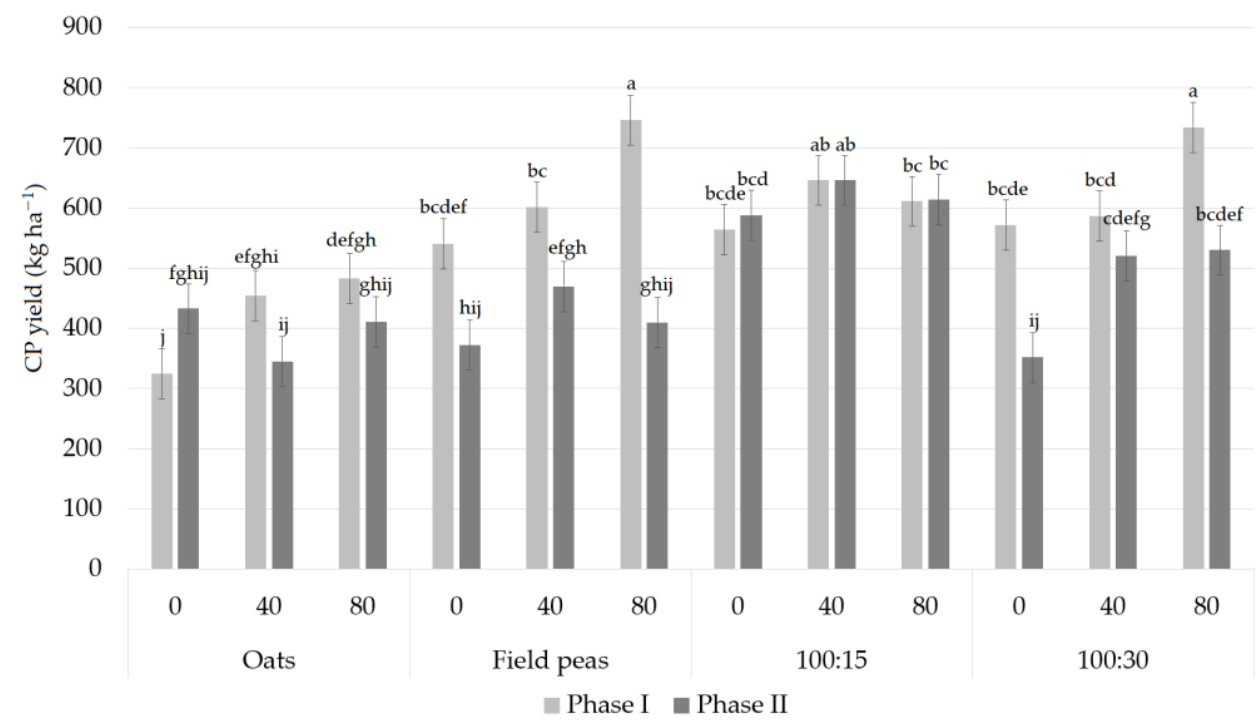

Figure 4. Crude protein yield of sole crops and their mixture under nitrogen fertilizer $\left(0 \mathrm{~kg} \mathrm{ha}^{-1}\right.$, $40 \mathrm{~kg} \mathrm{ha}^{-1}, 80 \mathrm{~kg} \mathrm{ha}^{-1}$ ) and two mowing phases (2016); error bars—standard error; ${ }^{\mathrm{a}-\mathrm{j}}$-significant differences between different treatments, ${ }^{a}$ representing the highest value, etc.

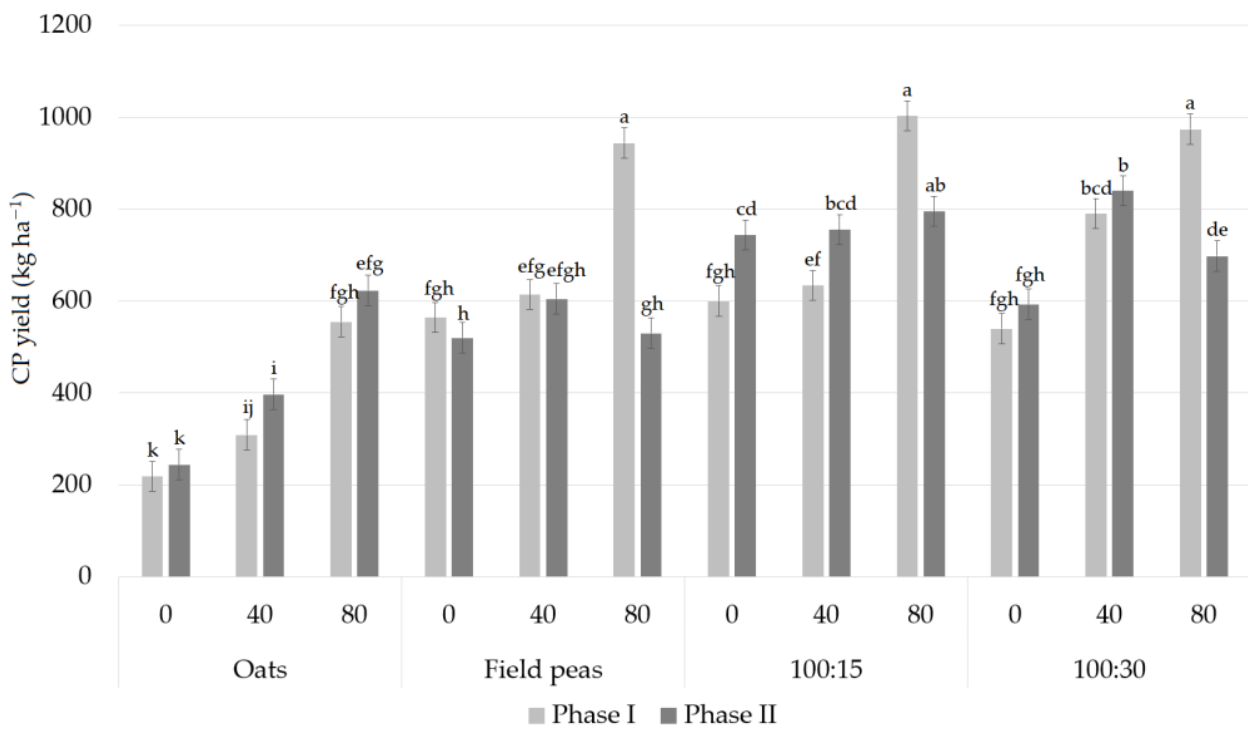

Figure 5. Crude protein yield of sole crops and their mixture under nitrogen fertilizer $\left(0 \mathrm{~kg} \mathrm{ha}^{-1}\right.$, $40 \mathrm{~kg} \mathrm{ha}^{-1}, 80 \mathrm{~kg} \mathrm{ha}^{-1}$ ) and two mowing phases (2017); error bars-standard error; ${ }^{\mathrm{a}-\mathrm{k}}$-significant differences between different treatments, ${ }^{a}$ representing the highest value, etc. 
Table 4. Different yield components of field pea and oat sole crops, and their mixtures under three fertilizer levels and two mowing stages.

\begin{tabular}{|c|c|c|c|c|c|c|c|c|c|c|c|c|c|c|c|}
\hline \multirow{2}{*}{$\begin{array}{c}\text { Tested Factors } \\
\text { Phase }\end{array}$} & \multicolumn{3}{|c|}{ Plant Height (cm) } & \multicolumn{3}{|c|}{ Number of Internodes } & \multicolumn{3}{|c|}{ Biomass Yield ( $\mathrm{tha}^{-1}$ ) } & \multicolumn{3}{|c|}{ Hay Yield $t$ ha $^{-1}$} & \multicolumn{3}{|c|}{ Crude Protein Yield $\left(\mathrm{kg} \mathrm{ha}^{-1}\right)$} \\
\hline & 2016 & 2017 & 2018 & 2016 & 2017 & 2018 & 2016 & 2017 & 2018 & 2016 & 2017 & 2018 & 2016 & 2017 & 2018 \\
\hline $\mathrm{I}$ & $112^{\mathrm{b}}$ & $100.1^{\mathrm{b}}$ & $87^{\mathrm{b}}$ & $15.2^{\mathrm{b}}$ & $14.5^{\mathrm{b}}$ & 14.3 & $22.79^{a}$ & $20.57^{a}$ & $18.71^{\mathrm{a}}$ & 4.51 & $4.64^{\mathrm{a}}$ & $3.41^{\mathrm{b}}$ & $572.3^{\mathrm{a}}$ & $645.5^{\mathrm{a}}$ & $642.4^{\mathrm{b}}$ \\
\hline II & $128^{\mathrm{a}}$ & $109.3^{a}$ & $99.5^{\mathrm{a}}$ & $16.4^{\mathrm{a}}$ & $15.6^{\mathrm{a}}$ & 14.6 & $19.14^{\mathrm{b}}$ & $17.98^{\mathrm{b}}$ & $17.58^{\mathrm{b}}$ & 4.64 & $4.43^{\mathrm{b}}$ & $4.48^{\mathrm{a}}$ & $474.3^{\mathrm{b}}$ & $612.2^{\mathrm{b}}$ & $822.4^{\mathrm{a}}$ \\
\hline \multicolumn{16}{|l|}{ Crop } \\
\hline Oats & - & - & - & - & - & - & $22.93^{\text {a }}$ & $17.55^{\mathrm{d}}$ & $19.34^{\text {a }}$ & $5.63^{\mathrm{a}}$ & $4.8^{\mathrm{b}}$ & $4.53^{\mathrm{a}}$ & $408.8^{\mathrm{c}}$ & $391.1^{c}$ & $568.3^{c}$ \\
\hline F. pea & 119.6 & $108.4^{\mathrm{a}}$ & $96.9^{\mathrm{a}}$ & $15.2^{\mathrm{b}}$ & 14.6 & $13.7^{\mathrm{b}}$ & $17.97^{\mathrm{b}}$ & $16.02^{c}$ & $16.13^{c}$ & $3.16^{\mathrm{c}}$ & $3.37^{\mathrm{c}}$ & $2.98^{\mathrm{c}}$ & $523.6^{\mathrm{b}}$ & $629.5^{b}$ & $747.5^{\mathrm{b}}$ \\
\hline $100: 15$ & 121.9 & $104.3^{\mathrm{b}}$ & $93.1^{\mathrm{ab}}$ & $16.3^{\mathrm{a}}$ & 15.2 & $14.8^{\mathrm{a}}$ & $21.25^{\mathrm{a}}$ & $21.07^{b}$ & $18.17^{\mathrm{b}}$ & $4.65^{\mathrm{b}}$ & $4.75^{\mathrm{b}}$ & $3.93^{\mathrm{b}}$ & $611.4^{\mathrm{a}}$ & $755.4^{\text {a }}$ & $824.4^{\mathrm{a}}$ \\
\hline $100: 30$ & 118.5 & $101.4^{\mathrm{b}}$ & $89.8^{\mathrm{b}}$ & $15.8^{\mathrm{ab}}$ & 15.4 & $14.8^{\mathrm{a}}$ & $21.71^{\text {a }}$ & $22.45^{a}$ & $18.96^{\mathrm{ab}}$ & $4.88^{\mathrm{b}}$ & $5.23^{\mathrm{a}}$ & $4.34^{\mathrm{a}}$ & $549.4^{\mathrm{b}}$ & $739.4^{\mathrm{a}}$ & $789.4^{\mathrm{a}}$ \\
\hline \multicolumn{16}{|l|}{$\mathrm{N}\left(\mathrm{kg} \mathrm{ha}^{-1}\right)$} \\
\hline 0 & 120.5 & $101.9^{\mathrm{b}}$ & 92.7 & 15.7 & 14.2 & 14.5 & $19.75^{b}$ & $16.1^{\mathrm{c}}$ & $17.4^{\mathrm{b}}$ & $4.31^{\mathrm{b}}$ & $3.45^{\mathrm{c}}$ & $3.71^{\mathrm{c}}$ & $468.3^{\mathrm{b}}$ & $503.0^{\mathrm{c}}$ & $657.4^{\mathrm{b}}$ \\
\hline 40 & 119.8 & $106.5^{\mathrm{a}}$ & 93.2 & 15.7 & 15.8 & 14.4 & $20.53^{b}$ & $19.31^{b}$ & $18.22^{\mathrm{a}}$ & $4.38^{\mathrm{b}}$ & $4.50^{\mathrm{b}}$ & $3.93^{\mathrm{b}}$ & $534.1^{\mathrm{a}}$ & $618.1^{\mathrm{b}}$ & $760.5^{\mathrm{a}}$ \\
\hline 80 & 119.5 & $105.7^{\mathrm{a}}$ & 93.9 & 15.9 & 15.2 & 14.5 & $22.61^{a}$ & $22.42^{a}$ & $18.83^{a}$ & $5.04^{a}$ & $5.66^{\mathrm{a}}$ & $4.19^{\mathrm{a}}$ & $567.5^{\mathrm{a}}$ & $765.4^{\mathrm{a}}$ & $779.4^{\mathrm{a}}$ \\
\hline \multicolumn{16}{|l|}{ F test } \\
\hline Phase & $* *$ & $* *$ & ** & $* *$ & * & ns & ** & ** & $* *$ & ns & * & $* *$ & ** & * & $* *$ \\
\hline Crop & ns & $* *$ & $* *$ & * & ns & $* *$ & $* *$ & ** & $* *$ & $* *$ & ** & ** & ** & ** & ** \\
\hline $\mathrm{N}^{\mathrm{T}}$ & ns & $*$ & ns & ns & ns & ns & $* *$ & ** & ** & $* *$ & ** & $* *$ & ** & ** & $* *$ \\
\hline Phase $\times$ Crop & ns & ns & ns & ns & ns & ns & ns & ns & ns & ns & ** & ns & $* *$ & $* *$ & ** \\
\hline Phase $\times \mathrm{N}^{1}$ & ns & ns & ns & ns & ns & ns & ns & $* *$ & ns & ns & ** & * & ns & ** & ** \\
\hline Crop $\times \mathrm{N}$ & ns & $* *$ & ns & ns & ns & ns & ns & ** & * & ns & ** & * & ns & ** & ** \\
\hline Phase $\times$ Crop $\times N$ & ns & * & ns & ns & ns & ns & $*$ & $* *$ & * & ns & * & ** & ns & $* *$ & ** \\
\hline
\end{tabular}

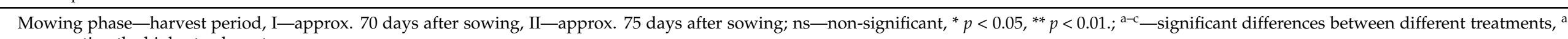
representing the highest value, etc. 


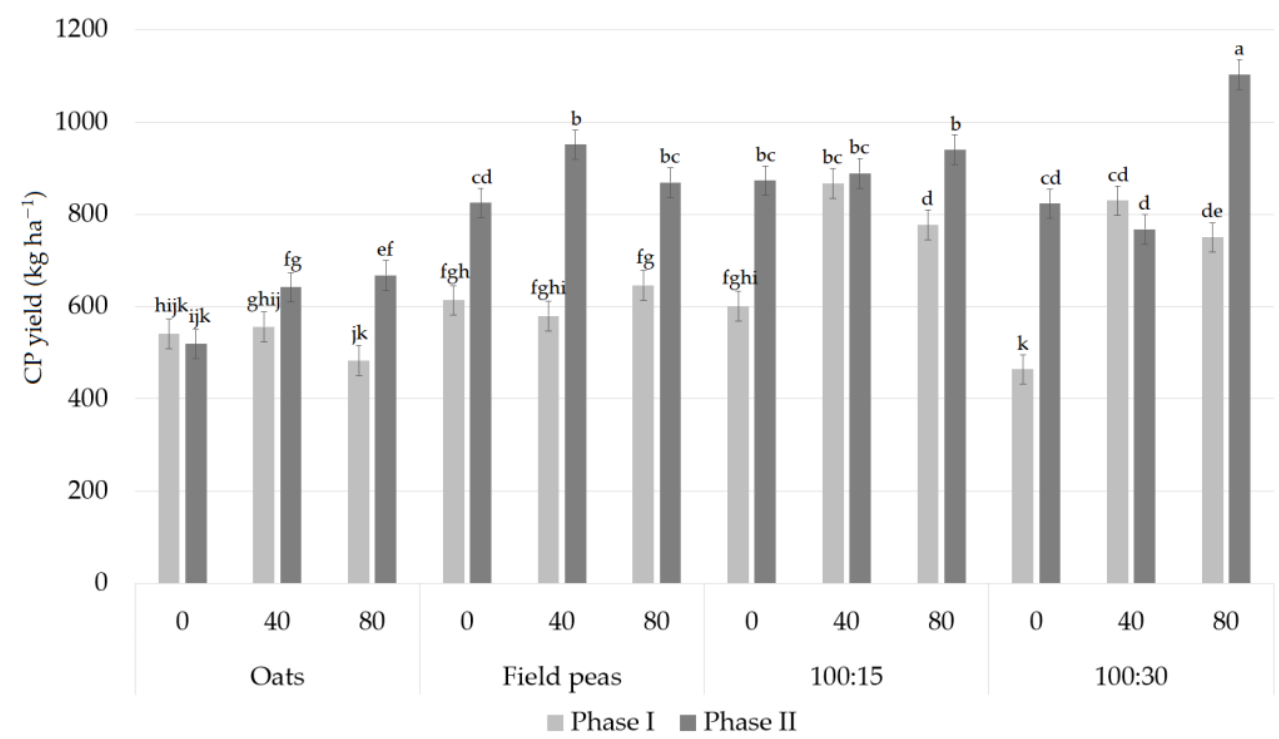

Figure 6. Crude protein yield of sole crops and their mixture under nitrogen fertilizer $\left(0 \mathrm{~kg} \mathrm{ha}^{-1}\right.$,

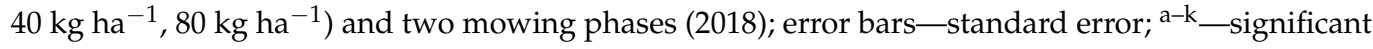
differences between different treatments, ${ }^{a}$ representing the highest value, etc.

\subsection{Field Peas Share in Yield and Land Equivalent Ratio}

Significant effects on the field peas' share of the yield was recorded for all tested factors. The mowing time had significant effects in the second and the third year $(p<0.01)$. Share in yield was significantly different between mixtures in all three years $(p<0.01)$, while the nitrogen had a significant effect in the first $(p<0.01)$ and second experimental years $(p<0.05)$. Significant interactions $(p<0.05)$ were recorded in the first year between the mowing phase and nitrogen $(p<0.05)$, and in the third year between the mowing phase and crop $(p<0.05)$.

Although the differences between the first and the second mowing phase were significant regarding the share in the yield of field peas, these differences were not consistent on a year-to-year basis. The sowing norm had a significant influence on the share of field pea in the yield $(p<0.01)$, and the higher share was recorded in the 100:15\% mixture for all three years (Table 5). Almost equal yields are observed between field pea and oats in the mixtures, even though field pea has a significantly higher sowing percentage. The average share in the yield for the mixture $100: 30 \%$ is $50.25 \%$, and for the mixture $100: 15 \%, 60.62 \%$. Nitrogen had a significant effect on the share of field peas in the yield as well, and it tends to decrease as the nitrogen increases. For all three years of testing, the amount of $80 \mathrm{~kg} \mathrm{ha}^{-1}$ $\mathrm{N}$ decreased the share of field peas by $8.26 \%$ and the amount of $40 \mathrm{~kg} \mathrm{ha}^{-1} \mathrm{~N}$ by $4.42 \%$. Regarding the particular mixture and nitrogen levels, for the 100:30\% mixture, the difference is mainly observed between no nitrogen application and applied nitrogen, regardless of the applied level, since there were no differences between 40 and $80 \mathrm{~kg} \mathrm{ha}^{-1} \mathrm{~N}$. For the mixture 100:15\%, the lowest field peas share in yield was recorded when $80 \mathrm{~kg} \mathrm{ha}^{-1} \mathrm{~N}$ was applied; however, differences compared to other levels were not significant throughout the years.

Significant effects of the tested factor on the land productivity were observed for the mowing phase in the first year and nitrogen in the second and the third year. No significant differences were observed between the mixtures. Second-order interactions were observed in the second year $(p<0.05)$ and first-order interactions between phase and nitrogen in the third year $(p<0.01)$. The productivity of intercropped field peas and oats is higher compared to sole crops. Intercropped field peas and oats almost always utilize the land more productively compared to sole crops. The average LER value within three factors and three years of testing is 1.18. The LER was significantly higher in the second mowing phase compared to the first, only in the first experimental year. 
Table 5. Field peas share in the biomass yield and LER for field peas and oats mixtures under different levels of nitrogen fertilizer in two mowing phases.

\begin{tabular}{|c|c|c|c|c|c|c|}
\hline \multirow{2}{*}{$\begin{array}{l}\text { Tested Factors } \\
\text { Mowing phase }\end{array}$} & \multicolumn{3}{|c|}{ Share in Yield \% } & \multicolumn{3}{|c|}{ LER } \\
\hline & 2016 & 2017 & 2018 & 2016 & 2017 & 2018 \\
\hline I & 58.32 & $57.30^{a}$ & $47.89^{b}$ & $1.03^{b}$ & 1.36 & 1.08 \\
\hline II & 61.75 & $51.23^{b}$ & $56.13^{a}$ & $1.27^{\mathrm{a}}$ & 1.3 & 1.05 \\
\hline \multicolumn{7}{|l|}{ Crop } \\
\hline 100:15 & $66.33^{a}$ & $56.86^{a}$ & $58.67^{a}$ & 1.17 & 1.29 & 1.05 \\
\hline 100:30 & $53.74^{\mathrm{b}}$ & $51.67^{\mathrm{b}}$ & $45.35^{b}$ & 1.14 & 1.37 & 1.07 \\
\hline \multicolumn{7}{|l|}{$\mathrm{N}\left(\mathrm{kg} \mathrm{ha}^{-1}\right)$} \\
\hline 0 & $65.88^{a}$ & $57.57^{\mathrm{a}}$ & 54.95 & 1.13 & $1.39^{\mathrm{a}}$ & $0.98^{b}$ \\
\hline 40 & $62.33^{\mathrm{a}}$ & $53.74^{\mathrm{a} b}$ & 50.83 & 1.19 & $1.42^{\mathrm{a}}$ & $1.1^{\mathrm{a}}$ \\
\hline 80 & $51.9^{b}$ & $51.48^{b}$ & 50.25 & 1.14 & $1.19^{b}$ & $1.11^{\mathrm{a}}$ \\
\hline \multicolumn{7}{|l|}{$\mathrm{F}$ test } \\
\hline Phase & ns & $* *$ & $* *$ & $* *$ & ns & ns \\
\hline Crop & $* *$ & ** & $* *$ & ns & ns & ns \\
\hline $\mathrm{N}$ & $* *$ & * & ns & ns & $*$ & $* *$ \\
\hline Phase $\times$ Crop & ns & ns & $*$ & ns & ns & ns \\
\hline Phase $\times \mathrm{N}$ & * & ns & ns & ns & ns & $* *$ \\
\hline Crop $\times \mathrm{N}$ & ns & ns & ns & ns & ns & ns \\
\hline Phase $\times$ Crop $\times N$ & ns & ns & ns & ns & $*$ & ns \\
\hline
\end{tabular}

Mowing phase - harvest period, I-approx. 70 days after sowing, II—approx. 75 days after sowing; ns—nonsignificant, ${ }^{*} 0.01<p<0.05,{ }^{* *} p<0.01 . ;{ }^{\mathrm{a}}$ b — significant differences between different treatments, ${ }^{\mathrm{a}}$ representing the highest value, etc.

\subsection{Economic Contributions of Field Pea and Oats Mixtures}

In Table 6, the inputs and output results for field pea and oat mixtures, fertilized by different nitrogen levels, are given. For both mixtures and each treatment, three-year average costs were calculated. The analysis included machinery operation cost with the labor force, raw material costs, output, net return, and benefit-cost ratio. It can be noted that total costs are primarily dominated by raw material costs $(63 \%), 64 \%$ for a $100: 15 \%$ and $100: 30 \%$ mixture. With a share of as much as $50 \%$, the most significant component of raw material costs is seed costs. However, the costs of machine operations, which include labor costs, account for about $36 \%$ of total costs. The economic analysis of the production for both mixtures indicates that a small net profit is realized even without the application of nitrogen fertilizer. For treatments without nitrogen, net returns of EUR 28.4 and EUR 39.4 were found in a mixture of 100:15\% and 100:30\%, respectively. The net returns were improved by the use of nitrogen fertilizer but with differences between mixtures and fertilization levels. While the net returns are increased by $123.6 \%$, the application of $40 \mathrm{~kg} \mathrm{ha}^{-1} \mathrm{~N}$ for $100: 15 \%$ mixture burdens the total costs by $4.6 \%$. A significant increase in the net returns was found in this mixture, especially by applying $80 \mathrm{~kg} \mathrm{ha}^{-1} \mathrm{~N}$. Here, crop fertilization burdens the total production costs by $6.9 \%$, as the net returns are increased by $164.4 \%$. However, it was found that with the increase in oats in the sowing norm, the economic efficiency of the nitrogen decreases. Namely, the costs of applying nitrogen fertilizer to the mixture $100: 30 \%$ are $4.5 \%$ and $6.7 \%$ of the total production costs, while the profit increases by $3.6 \%$ and $137.3 \%$ by applying 40 and $80 \mathrm{~kg} \mathrm{ha}^{-1} \mathrm{~N}$. 
Table 6. Economic contributions of field pea and oats mixtures under various treatments with nitrogen.

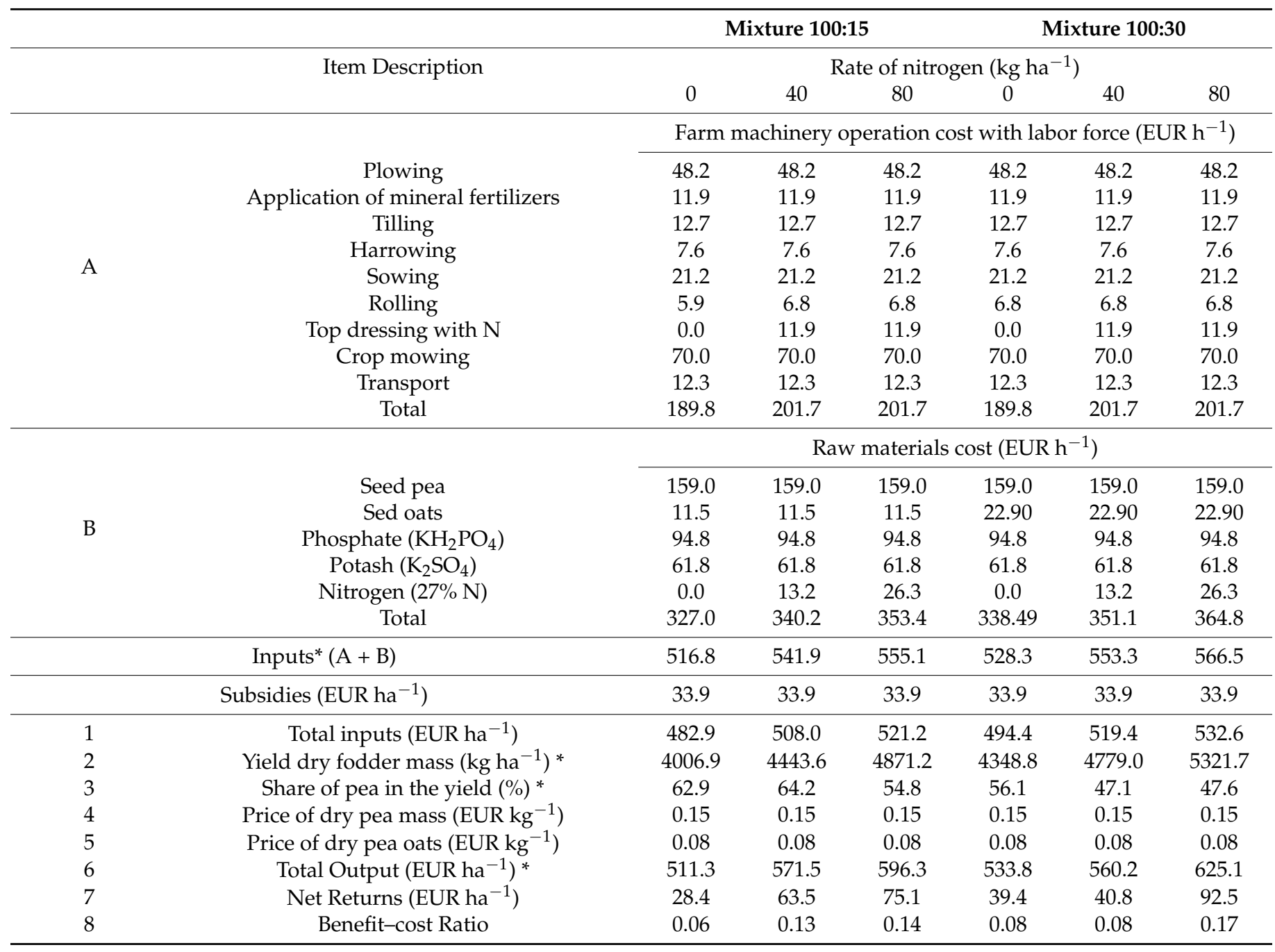

* Averages of 2016, 2017 and 2018.

Although the benefit-cost ratio of any treatment is not greater than 1 , it can be observed that on the values of the nitrogen-free treatment are the lowest. In the mixture of 100:15\%, with the application of $40 \mathrm{~kg} \mathrm{ha}^{-1} \mathrm{~N}$, the benefit-cost ratio was increased by $100 \%$, while the treatment with $80 \mathrm{~kg} \mathrm{ha}^{-1} \mathrm{~N}$ increased by $133.3 \%$. However, in the mixture of $100: 30 \%$, $40 \mathrm{~kg} \mathrm{ha}^{-1} \mathrm{~N}$ did not increase the Benefit-cost Ratio, while the treatment of $80 \mathrm{~kg} \mathrm{ha}^{-1} \mathrm{~N}$ showed an increase of $112.5 \%$.

\section{Discussion}

Intercropping field peas with oats is a better way of forage production compared to growing sole crops. Understanding some significant moments in their cultivation, such as nitrogen application, sowing ratios, and time of harvest, can increase the cultivation success and give profitable returns.

Soil conditions varied on a year-to-year basis, from below average in the first year to average in the second and the third year. The climate conditions for the period of rapid biomass development were arid to semi-arid in all three years of research; however, the period that coincides with the initial development phases was generally humid. Issues with the growth or damage caused by biotic or abiotic factors were not observed, and crops had normal development. Based on these observations, we have concluded that the crops had favorable conditions for proper development but not such favorable conditions as to reach their full potential, primarily to achieve high yields. 


\subsection{Plant Height and the Number of Internodes}

These results are higher in the second mowing phase. Similar trends have been observed in previous studies of field peas and their mixtures [6]. This increase is caused by the continuation of plant growth after the generative parts (flower buds and flowers) have been formed. Mixing field peas with oats tends to decrease the height of field peas, but in contrast, the number of internodes tends to increase. The number of internodes is significant since they correlate with the number of leaves on the plant, which are the main contributors to the biomass. The increase in this trait is favorable in the mixture, and the results show a positive effect of oats as a supporting crop to the field pea. Nitrogen had a negligible effect on both yield components.

\subsection{Biomass and Hay Yields}

Biomass yields were significantly higher in the first mowing phase compared to the second for all crops. Similar trends have been observed in other research into field pea, vetch, and oat mixtures as well as sole crops [33]. It is important to note that the mowing phase is not the best indicator of productivity regarding biomass yields. The crops usually retain excess water in their biomass, and changes between phases are highly affected by the factors related to the current humidity, rainfall, wind and aeration of the field, etc. Field peas and oats in the mixture achieved higher yields compared to sole field peas for all three years. This is expected as sole oats provide higher yields compared to sole field peas, and as its share in the sowing norm increases, the yields increase. Thus the 100:30\% mixture achieved significantly higher biomass yields compared to the 100:15\% mixture. Higher biomass yields of intercropped species compared to sole crops were recorded in previous studies at the same locality and in similar growing conditions [6].

Accordingly, the higher percentage of oats in the sowing norm tends to increase dry weight yields. Similar findings have been noted in other researches [19,34,35]. In one study, the average dry mass yields for different mixtures of field peas and oats are $10.15 \mathrm{tha}^{-1}$ (75P:25O), $12.7 \mathrm{t} \mathrm{ha}^{-1}$ (50P:50O), and $13.58 \mathrm{tha}^{-1}$ (25P:75O) [34]. Other research reports the range from $9.89 \mathrm{tha}^{-1}$ for the mixture 65P:35O and $11.27 \mathrm{tha}^{-1}$ for the mixture 55P:45O [19]. The same was observed when field peas were grown with barley. These findings point to the conclusion that oats serve as an important supporting crop that can significantly correct field pea yields. Nitrogen fertilizer increased biomass and hay yields for sole crops and their mixtures. Similar findings have been recorded in other researches [9]. Analysis has shown that nitrogen fertilizer has a pronounced effect on the biomass and hay yield of oats compared to field peas. This can be explained by the higher competitiveness of oats for nitrogen, as some research indicates [21].

\subsection{Crude Protein Yields}

It is often the case that the crude protein content of sole field peas exceeds the protein content of its mixtures $[4,19,34]$. However, as shown in the section on yield, field peas achieved lower biomass yields compared to mixtures. For this reason, the total yield of crude protein in sole field peas will likely be lower than the protein yield in its mixtures with cereals, which has been observed in our experiment as well as other studies $[4,19,34]$. An increase in oats in the sowing norm led to a decrease in protein yields, and the same findings are recorded in other researches [4]. In this research work, the protein content of field peas and oats, and field peas and barley with the sowing norm of $80: 20 \%$ is $132 \mathrm{~g} \mathrm{~kg}^{-1}$; $130 \mathrm{~g} \mathrm{~kg}^{-1}$ (respectively), and this content is significantly higher compared to the mixtures with a ratio of $60: 40 \%\left(115 \mathrm{~g} \mathrm{~kg}^{-1} ; 111 \mathrm{~g} \mathrm{~kg}^{-1}\right.$, respectively). Similar trends have been recorded in other studies as well $[19,36]$. The highest protein content was achieved in the single-grown field peas, but in terms of protein yield, field peas had the lowest yields due to having the lowest biomass yields. 


\subsection{Field Peas' Share in the Yield and LER}

Field peas and oat mixtures affected by different sowing norms show a particular pattern. As the oats in the sowing norm increase, the hay and biomass yields increase. However, as the oats in the sowing norm increase, the fiber content increases in the feed, which leads to a decrease in the protein component. The examined results for protein yields show that higher yields were achieved in the 100:15\% mixture, compared to the 100:30\% mixture for all three years. Only after the nitrogen is added in the cultivation do the protein yields of the 100:30\% mixture start to increase and reach the yields of the 100:15\% mixture. It has been concluded that mixtures with higher seed ratios of oats, such as 100:30\%, need nitrogen fertilizer to correct their protein yields.

Analysis has shown that field peas and oats achieve an almost equal share in the yields, even though oats are present in much smaller sowing percentages. In other research, the average share of field pea in the yield is $50.68 \%$ for the mixture of field pea and triticale-75:25\% [36]. In that study, triticale, with a much lower share in the sowing norm, achieves the same share in the yield as a field pea cultivar Ürünlü. An even lower share in the yield was observed for a second field pea cultivar (21.71\%-Ulubatli). This shows the high competitiveness of oats compared to field peas, and similar findings have been observed in other studies [4,36]. Higher competitiveness has been observed for grasses over legumes in general [37]. As previously discussed, nitrogen fertilizer also tends to favor the oat component. A combined analysis of variance for three years showed a significant interaction between the sowing rates and nitrogen fertilizer. Consequently, the share of field pea in the mixture decreases as the nitrogen fertilization and oat seed ratios are increasing. The field pea and oat mixtures better utilize the soil compared to the sole crops. Higher productivity for the same unit of land has been observed in other studies of intercropped field peas and oats or other cereals $[4,19,38]$.

\subsection{Economic Analysis}

The results showed that growing a mixture of field peas and oats achieves higher yields compared to individually grown crops. Positive results are further achieved by applying nitrogen fertilizer. The economic analysis showed that the application of nitrogen fertilizers increases the total costs in the range of 4.5 to $6.9 \%$, but the net returns are also increased - by 3.6 to $164.4 \%$, depending on the mixture and fertilizer levels. Additionally, higher economic efficiency of nitrogen fertilizer application was found in the mixture of $100: 15 \%$ compared to the $100: 30 \%$ mixture, considering the obtained differences between net returns and Benefit-cost Ratio between treatments. The obtained results lead to the conclusion that as the share of oats in the sowing norm increases, the economic efficiency of the nitrogen fertilizer decreases. Several studies emphasize that the application of nitrogen in mixed crops of legumes and cereals affects competition among crops, their yield, and the nitrogen yield of the individual crops [15].

\section{Conclusions}

Intercropping field pea and oats is a superior way of forage production compared to growing sole crops. In our experiment, the main reasons for such a conclusion are higher productivity (average LER-1.18), higher crude protein yields, and fresh and dry weight yields. Changing the share of oats in the sowing norm had a significant effect on the yields. Both fresh and dry weight yields were higher when oats in the sowing norm were higher: 100:30-4.82 $\mathrm{tha}^{-1} ; 100: 15-4.44 \mathrm{tha}^{-1}$; field pea-3.17 $\mathrm{tha}^{-1}$, of dry weight. This indicates that oats can significantly correct the yield of field pea. However, as the oats' sowing norm increases, crude protein decreases, 100:15-730.4 kg ha ${ }^{-1}$; 100:30—692.7 kg ha ${ }^{-1}$; field pea-633.5 $\mathrm{kg} \mathrm{ha}^{-1}$; oats-456.1 $\mathrm{kg} \mathrm{ha}^{-1}$. Nitrogen fertilizer is a significant factor in their production since it significantly increases the yields. Both levels gave positive results compared to the control treatment, but $80 \mathrm{~kg} \mathrm{ha}^{-1} \mathrm{~N}$ gave better results compared to $40 \mathrm{~kg} \mathrm{ha}^{-1} \mathrm{~N}$. The addition of nitrogen into the production does not increase the overall cost significantly, but the net profits can be increased by as much as $163 \%$. Nitrogen 
fertilizer also achieves higher economic efficiency for the mixture 100:15\% compared to the 100:30\% mixture. The effect of the mowing phase was present but not as consistent as the previous two factors. The difference in the crude protein yield was not consistent and depended highly on the year of cultivation. The chemical composition and biomass quality generally tend to decrease when crop matures; however, further chemical analysis is required to understand the full effects of this factor.

Author Contributions: Conceptualization, A.S., S.B. and S.K.; methodology, A.S., S.B. and S.K.; validation, A.S., S.K. and Ž.D.; formal analysis, I.K., Ž.D., S.R.N. and S.B.; resources, A.S., S.B. and S.K.; data curation, I.K. and A.S.; writing-original draft preparation, I.K. and A.S.; writing-review and editing, A.S.; supervision, A.S. and Ž.D.; project administration, S.R.N. and J.D. All authors have read and agreed to the published version of the manuscript.

Funding: This research received no external funding.

Institutional Review Board Statement: Not applicable.

Informed Consent Statement: Not applicable.

Data Availability Statement: The data presented in this study are available on request from the corresponding author.

Acknowledgments: This research was supported by the Ministry of Education Science and Technological Development, Republic of Serbia. Number of the Agreement on realization and financing of scientific research work NIO, 2021. 451-03-9/2021-14/ 200216.

Conflicts of Interest: The authors declare no conflict of interest.

\section{References}

1. Watson, C.A.; Reckling, M.; Preissel, S.; Bachinger, J.; Bergkvist, G.; Kuhlman, T.; Lindström, K.; Nemecek, T.; Topp, C.F.E.; Vanhatalo, A.; et al. Chapter Four-Grain Legume Production and Use in European Agricultural Systems. Adv. Agron. 2017, 144, 235-303.

2. Samardžić, M.; Vasin, J.; Jajić, I.; Latković, D.; Andreeva, I.; Vasenev, I. Impact of Different Agricultural Practices on Soil Organic Matter Content in Chernozems of the Vojvodina region. Geophys. Res. Abstr. 2018, 20, EGU2018-13902.

3. Tsiafouli, M.A.; Thébault, E.; Sgardelis, S.P.; De Ruiter, P.C.; van der Putten, W.H.; Birkhofer, K.; Hemerik, L.; de Vries, F.T.; Bardgett, R.D.; Brady, M.V.; et al. Intensive agriculture reduces soil biodiversity across Europe. Glob. Chang. Biol. 2014, 21, 973-985. [CrossRef] [PubMed]

4. Dordas, C.A.; Vlachostergios, D.N.; Lithourgidis, A.S. Growth dynamics and agronomic-economic benefits of pea-oat and pea-barley intercrops. Crop Pasture Sci. 2012, 63, 45-52. [CrossRef]

5. Bacchi, M.; Monti, M.; Calvi, A.; Lo Presti, E.; Pellicanò, A.; Preiti, G. Forage Potential of Cereal/Legume Intercrops: Agronomic Performances, Yield, Quality Forage and LER in Two Harvesting Times in a Mediterranean Environment. Agronomy 2021, 11, 121. [CrossRef]

6. Krga, I.; Simić, A.; Bijelić, Z.; Mandić, V.; Vasiljević, S.; Karagić, Đ.; Milić, D. Interspecies relations and yield of different field pea/oats mixtures. In Analele Universitatii din Craiova-Agricultura, Montanologie, Cadastru; University of Craiova: Craiova, Romania, 2016; Volume 46, pp. 199-205.

7. Daryanto, S.; Fu, B.; Zhao, W.; Wang, S.; Jacinthe, P.-A.; Wang, L. Ecosystem service provision of grain legume and cereal intercropping in Africa. Agric. Syst. 2020, 178, 102761. [CrossRef]

8. Ginwal, D.S.; Kumar, R.; Ram, H.; Meena, R.K.; Kumar, U. Quality characteristics and nutrient yields of maize and legume forages under changing intercropping row ratios. Indian J. Anim. Sci. 2019, 89, 281-286.

9. Cowden, R.J.; Shah, A.N.; Lehmann, L.M.; Kiær, L.P.; Henriksen, C.B.; Ghaley, B.B. Nitrogen Fertilizer Effects on Pea-Barley Intercrop Productivity Compared to Sole Crops in Denmark. Sustainability 2020, 12, 9335. [CrossRef]

10. Rodriguez, C.; Carlsson, G.; Englund, J.-E.; Flöhr, A.; Pelzer, E.; Jeuffroy, M.-H.; Makowski, D.; Jensen, E.S. Grain legume-cereal intercropping enhances the use of soil-derived and biologically fixed nitrogen in temperate agroecosystems. A meta-analysis. Eur. J. Agron. 2020, 118, 126077. [CrossRef]

11. Zhao, J.; Zeng, Z.; He, X.; Chen, H.; Wang, K. Effects of monoculture and mixed culture of grass and legume forage species on soil microbial community structure under different levels of nitrogen fertilization. Eur. J. Soil Biol. 2015, 68, 61-68. [CrossRef]

12. Bedoussac, L.; Journet, E.; Hauggaard-Nielsen, H.; Naudin, C.; Corre-Hellou, G.; Jensen, S.E.; Prieur, L.; Justes, E. Eco-logical principles underlying the increase of productivityachieved by cereal-grain legume intercrops in organic farming. A review. Agron. Sustain. Dev. 2015, 35, 911-935. [CrossRef]

13. Shao, Z.; Wang, X.; Gao, Q.; Zhang, H.; Yu, H.; Wang, Y.; Zhang, J.; Nasar, J.; Gao, Y. Root Contact between Maize and Alfalfa Facilitates Nitrogen Transfer and Uptake Using Techniques of Foliar 15N-Labeling. Agronomy 2020, 10, 360. [CrossRef] 
14. Thilakarathna, M.S.; McElroy, M.S.; Chapagain, T.; Papadopoulos, Y.A.; Raizada, M.N. Belowground nitrogen transfer from legumes to non-legumes under managed herbaceous cropping systems. A review. Agron. Sustain. Dev. 2016, 36, 58. [CrossRef]

15. Neugschwandtner, R.W.; Kaul, H.-P. Nitrogen uptake, use and utilization efficiency by oat-pea intercrops. Field Crops Res. 2015, 179, 113-119. [CrossRef]

16. Šarūnaite, L.; Deveikyte, I.; Arlauskiene, A.; Kadžiuliene, Ž.; Maikšteniene, S. Pea and spring cereal intercropping systems: Advantages and suppression of broad-leaved weeds. Pol. J. Environ. Stud. 2012, 22, 541-551.

17. Gronle, A.; Böhm, H.; Heß, J. Weed suppressive ability in sole and intercrops of pea and oat and its interaction with ploughing depth and crop interference in organic farming. Org. Agric. 2015, 5, 39-51. [CrossRef]

18. Lorin, M.; Jeuffroy, M.-H.; Butier, A.; Valantin-Morison, M. Undersowing winter oilseed rape with frost-sensitive legume living mulches to improve weed control. Eur. J. Agron. 2015, 71, 96-105. [CrossRef]

19. Kocer, A.; Albayrak, S. Determination of forage yield and quality of pea (Pisum sativum L.) mixtures with oat and barley. Turk. J. Field Crops 2012, 17, 96-99.

20. Vann, R.A.; Reberg-Horton, S.C.; Castillo, M.S.; McGee, R.J.; Mirsky, S.B. Winter Pea, Crimson Clover, and Hairy Vetch Planted in Mixture with Small Grains in the Southeast United States. Agron. J. 2019, 111, 805-815. [CrossRef]

21. Tsialtas, I.T.; Baxevanos, D.; Vlachostergios, D.N.; Dordas, C.; Lithourgidis, A. Cultivar complementarity for symbiotic nitrogen fixation and water use efficiency in pea-oat intercrops and its effect on forage yield and quality. Field Crops Res. 2018, 226, 28-37. [CrossRef]

22. Neugschwandtner, R.W.; Kaul, H.-P. Sowing ratio and N fertilization affect yield and yield components of oat and pea in intercrops. Field Crops Res. 2014, 155, 159-163. [CrossRef]

23. Pellicanò, A.; Romeo, M.; Pristeri, A.; Preiti, G.; Monti, M. Cereal-pea intercrops to improve sustainability in bioethanol production. Agron. Sustain. Dev. 2015, 35, 827-835. [CrossRef]

24. Baxevanos, D.; Tsialtas, T.I.; Vlachostergios, N.D.; Hadjigeorgiou, I.; Dordas, C.; Lithourgidis, A. Cultivar competitiveness in pea-oat intercrops under Mediterranean conditions. Field Crops Res. 2017, 214, 94-103. [CrossRef]

25. Li, Y.; Pan, F; Yao, H. Response of symbiotic and asymbiotic nitrogen-fixing microorganisms to nitrogen fertilizer application. J. Soils Sediments 2019, 19, 1948-1958. [CrossRef]

26. Meier, U. Growth Stages of Mono-and Dicotyledonous Plants-BBCH Monograph; Federal Biological Research Centre for Agriculture and Forestry: Bonn, Germany, 2001; p. 139.

27. AOAC. Official Methods of Analysis of the AOAC, 15th ed; Method 984.13; Association of Official Analytical Chemists: Arlington, VA, USA, 1990.

28. Milentijević, N.; Dragojlović, J.; Ristić, D.; Cimbaljević, M.; Demirović, D.; Valjarević, A. The assessment of aridity in Leskovac basin, Serbia (1981-2010). J. Geogr. Inst. Jovan Cvijic, SASA 2018, 68, 249-264. [CrossRef]

29. Mead, R.; Willey, R.W. The Concept of a 'Land Equivalent Ratio' and Advantages in Yields from Intercropping. Exp. Agric. 1980, 16, 217-228. [CrossRef]

30. Subić, J.; Roljević Nikolić, S.; Simonović, Z. Evaluation of economic sustainability ecological production vegetables on family farms in Serbia. In Proceedings of the International Symposium “Agrarian Economy and Rural Development—Realities and Perspectives for Romania”, Bucharest, Romania, 14 November 2019; pp. 35-44.

31. Yang, C.; Fan, Z.; Chai, Q. Agronomic and Economic Benefits of Pea/Maize Intercropping Systems in Relation to N Fertilizer and Maize Density. Agronomy 2018, 8, 52. [CrossRef]

32. Ballabio, C.; Lugato, E.; Fernández-Ugalde, O.; Orgiazzi, A.; Jones, A.; Borrelli, P.; Montanarella, L.; Panagos, P. Mapping LUCAS topsoil chemical properties at European scale using Gaussian process regression. Geoderma 2019, 355, 113912. [CrossRef]

33. Blagojević, M.B. Effect of Mutual Relationship, Stage of Development and Inoculation on Silage Quality of Annual Legume and Grain. Ph.D. Thesis, Faculty of Agriculture, University of Belgrade: Belgrade, Serbia, 2017; p. 41. Available online: https:/ / nardus.mpn.gov.rs/bitstream/id/13739/Disertacija.pdf (accessed on 7 April 2021).

34. Uzun, A.; Asik, F. The effect of Mixture rates and cutting stages on some yield and quality characters of pea (Pisum sativum L.) + oat (Avena sativa L.) mixture. Turk. J. Field Crop 2012, 17, 62-66.

35. Maxin, G.; Andueza, D.; Le Morvan, A.; Baumont, R. Effect of intercropping vetch (Vicia sativa L.), field pea (Pisum sativum L.) and triticale (X Triticosecale) on dry-matter yield, nutritive and ensiling characteristics when harvested at two growth stages. Grass Forage Sci. 2017, 72, 777-784. [CrossRef]

36. Aşci, Ö.Ö.; Acar, Z.; Arici, Y.K. Hay yield, quality traits and interspecies competition of forage pea-Triticale mixtures harvested at different stages. Turk. J. Field Crops 2015, 20, 166-173. [CrossRef]

37. Yu, Y.; Stomph, T.-J.; Makowski, D.; Zhang, L.; van der Werf, W. A meta-analysis of relative crop yields in cereal/legume mixtures suggests options for management. Field Crops Res. 2016, 198, 269-279. [CrossRef]

38. Chen, C.; Westcott, M.; Neill, K.; Wichman, D.; Knox, M. Row Configuration and Nitrogen Application for Barley-Pea Intercropping in Montana. Agron. J. 2004, 96, 1730-1738. [CrossRef] 